\title{
Editorial
}

\section{O Brasil: de títulos acadêmicos e ingenuidade nas pesquisas a empresários imediatistas}

Nas universidades brasileiras ainda se discute se a meritocracia é algo bom ou ruim. São debatidos em conselhos universitários se ações à margem da lei devem ou não ser punidas pelas entidades formais constituídas pela sociedade em geral. Estes dois pontos são exemplos típicos do caos institucional implantado nas universidades brasileiras. Este caos começa a ganhar corpo na última década a partir de pequenos núcleos de professores improdutivos, que sob a égide da implantação de uma justiça social, conduziram as universidades a uma decadência nunca vista neste país. Associado a este caos institucional em que o tema do livro de George Orwell, a revolução dos bichos, muito bem se assemelha, existe a ingenuidade da grande maioria dos professores quanto à gestão do ensino, da pesquisa e do desenvolvimento tecnológico. Esta falta de gestão é uma herança histórica brasileira em que os dirigentes das instituições montam programas miraculosos e nunca ações efetivas. $\mathrm{O}$ último destes programas vem dentro da concepção de que ganhar cultura tem como consequência direta o desenvolvimento do país. A repetição das mesmas ações falhas do passado se intensifica atualmente.

$\mathrm{O}$ envio indiscriminado de jovens para o exterior dentro do programa ciência sem fronteiras vem sendo conhecido no exterior por "turismo sem fronteiras". Tudo isto acontece em função de uma falta de conhecimento de como a transformação acontece de fato nos poucos nichos produtivos deste país. Há a ilusão de que o simples estar em uma instituição é o suficiente para produzir uma transformação.

A própria concepção dos programas de pós-graduação produz para o Brasil resultados pífios, pois eles são arraigadamente baseados no formato de cursos. Embora neste formato, pelo menos inicialmente eram em regime integral. Agora se consolidaram fatalmente como cursos, mas gradativamente em regime parcial e com um crescendo no objetivo de uma formação individual em detrimento de uma consolidação institucional. Assim, os laboratórios não criam massa crítica para trabalhos cooperativos com o setor empresarial. Os programas de pós-graduação deveriam abolir a conotação de cursos para fazer com que os pós-graduandos não se sentissem e se comportassem como alunos. O comportamento atual dos pós-graduandos não remete a atitudes profissionais e não caracterizam o ambiente de trabalho com um verdadeiro instituto de pesquisa e desenvolvimento.

Ao orientar um trabalho de pós-graduação um professor tem que se ver como um gestor de uma organização. Ele deve organizar o encaminhamento dos trabalhos de forma a contribuir com o fortalecimento da infraestrutura de sua instituição. Ou seja, os temas dos trabalhos não devem ser um assunto estanque num ritual a cadêmico. Se cair neste ritual, o candidato não se torna um profissional. Ele estará sendo estimulado a não cumprir horário e a instituição não criará o intercâmbio diário de informações entre seus membros. Neste caso, a pós-graduação se afigura realmente como um curso e não como um programa gerador de conhecimentos e criador de estruturas consolidadas para o desenvolvimento científico e tecnológico.

É com um trabalho associativo num ambiente que não só pareça, mas que demonstre participação, que exercitamos nossa criatividade e criamos soluções para os problemas da vida. É necessário sair da acomodação, criar novas idéias e trabalhar com amor e determinação. Esta determinação foi e é o principal esteio de nações desenvolvidas. Pelo vivenciar coletivo dos sucessos e insucessos das pesquisas, uma instituição se amalgama para enfrentar novos tempos e para contribuir com a melhoria da qualidade de vida do país. As universidades alemãs, por exemplo, embora mantendo um relacionamento internacional, não se curvam sectariamente a índices burocráticos como o de publicações em determinadas revistas, ditas de impacto. Sua fama vem do poder transformador da sociedade. Não há a pós-graduação no sentido estrito da que conhecemos no Brasil. O título acadêmico não é um objetivo em si, mas uma consequência de um trabalho relevante para a universidade que normalmente está associado inalienavelmente às necessidades da sociedade. Aqui no Brasil, a universidade perde seu tempo em lutas político-partidárias, chegando muitas vezes a um confronto entre sua direção e as polícias e na discussão de permitir ou não o uso de drogas em seu recinto, como foi e está sendo o caso do episódio iniciado na UFSC em 25 de março próximo passado. Então, o ambiente onde era para surgir idéias e ideais para a solução dos grandes problemas nacionais, não induz a desafios e pelo contrário, tolhe iniciativas com base em um sectarismo político que está falido no mundo há algumas décadas.

Por outro lado, o empresariado brasileiro não foi amalgamado pela luta do começar pequeno e ir sedimentando um caminho como aos moldes do que aconteceu nos países ricos do mundo. Isto se caracteriza em um grande inconveniente para uma aproximação entre a academia e o setor produtivo. Um não assimila e interage com o outro, salvo raras exceções.

Jair Carlos Dutra

Professor Titular

Departamento de Engenharia Mecânica

Universidade Federal de Santa Catarina

DOI: http://dx.doi.org/10.1590/0104-9224/SI1903.01 